\title{
SOCIAL NETWORKING AND THE DEVELOPMENT OF NEW VENTURES
}

\author{
Karl Wennberg and Henrik Berglund
}

\begin{abstract}
This chapter takes a closer look at how social networks can affect the early development of new ventures. The dynamic role of social networks is discussed and exemplified by two longitudinal cases that illustrate the radically different ways in which social networks can influence venture development. These differences relate to social or individual ownership of the innovation process, to risks or opportunities as the focus of attention, and to the creative relationship between networking and financial bootstrapping techniques.
\end{abstract}

\section{INTRODUCTION}

Innovation, bringing something new and valuable to the market, is generally acknowledged as central to job creation, economic growth and industrial dynamics. New innovative ventures play a crucial role in this process because they are not constrained by routines and dominating logics to the same extent as large firms (Chesbrough \& Rosenbloom, 2002), which in

Innovation Through Collaboration

Advances in Interdisciplinary Studies of Work Teams, Volume 12, 203-225

Copyright (C) 2006 by Elsevier Ltd.

All rights of reproduction in any form reserved

ISSN: 1572-0977/doi:10.1016/S1572-0977(06)12008-7 
turn allows them to assume risks and pursue opportunities that larger firms avoid. Despite the recognized importance of agility and strategic flexibility, most research on innovation in new ventures examines individual entrepreneurs with one invention or idea, pursuing a single business opportunity from conception to completion (Van de Ven \& Engleman, 2004).

A number of researchers have sought a complementary perspective by highlighting how networks and contextual embeddedness affect the innovation process. Reliance on network contacts is especially important among new emerging ventures because of their limited resource base (Birley, 1985; Greene \& Brown, 1997). Cooper, Folta, and Woo (1995) showed that inexperienced entrepreneurs tend to rely more on personal ties such as family, friends, and other business owners, compared to experienced entrepreneurs who use professional contacts such as lawyers and accountants during the start-up phase. Yet, most studies treat networks, individuals, and ventures as separate and stable entities, with focus on testing how variance in the former (e.g. strength or number of network ties) affect some outcome in the latter (e.g. firm growth or survival) (Hoang \& Antoncic, 2003).

This chapter uses a social network perspective to investigate the role of collaboration through social networks in the innovative processes of two new independent ventures. A social network approach allows us to explore how new ventures develop without constraining our focus to specific individuals or inventions (Jack \& Andersen, 2002). What distinguishes this study, and where our approach takes a detour from much prior research, is the focus on the new venture as unit of analysis. We approached a wide range of stakeholders involved in two ventures, to discern how they and their social networks affected their development.

These cases are used to discuss the role of individual versus social ownership of the innovation process, attitudes toward risk and uncertain opportunities, and how entrepreneurs use their social network to gain access to information and resources, bootstrapping their ventures. We conclude by offering some brief implications for practitioners and policymakers as well as discussing potential avenues for further research.

\section{SOCIAL NETWORKS AND INNOVATION}

A social network perspective indicates the relationships between entrepreneurs and others that help them to access information and resources 
necessary to build a venture (Greve \& Salaff, 2003; Johannisson, 2000). These relationships are typically investigated from either the network or the individual perspective. Perhaps the most elaborate theoretical framework of how social networks influence new venture development, is Larson and Starr's (1993) network model of organization formation, where entrepreneurs' relationships develop from a set of relatively simple, personal and one dimensional exchanges, into a network of stable, multidimensional and multi-layered relationships. The entrepreneur's and other stakeholders' separate contacts thus gradually develop into a more cohesive network that shapes the new firm. However, Larson and Starr tend to underestimate the role of networks in the very early venture formation phase, as their model assumes that entrepreneurs begin their search for appropriate contacts once the decision to start has already been made (Hoang \& Antoncic, 2003). Others have suggested that both the identification and manner of exploration of new opportunities, is borne out of their existing networks (Birley, 1985; Davidsson \& Honig, 2003).

Hite $(2003,2005)$ instead puts forth a more fine-grained conceptualization of social networks. On this account, a social network is made up of more or less relationally embedded ties. That is, a specific network tie between an entrepreneur and another person is seldom characterized by pure economic exchange or pure social relationship but is somewhere on a continuum (Hite, 2003). A social network can be understood in terms of three distinct types of relationships: (1) personal relationships, (2) social capital, (3) dyadic economic interaction, or a mixture between these. The difference in these three types of embedded ties lies in the variation of the type of social relationship in which they are embedded (Hite, 2003). Sources of interpersonal trust and mechanisms of control accordingly differ between the three relational types: (a) network ties based on social capital dependent on reputational control and trust built through a third party, (b) network ties based on economic interaction depend on control stemming from the joint value of the relationship history, (c) and personal/competency trust such as goal congruence.

The type of network ties to a large extent determines how entrepreneurs are influenced by their external relationships. For instance, a close friend or relative may offer information or resources that persuade the entrepreneur away from a preferred economic choice (Staber \& Aldrich, 1995). Whereas many network ties are initially based on personal relationships or economic exchange, the interaction spawned by the venturing process often develops and strengthens the tie, making it both personally and economically embedded (Hite, 2005). 
As personal and economical relations overlap, it is difficult to know which relationships will turn out to be important for the venture. Network relationships and social capital are typically built up for reasons other than their potential economic value (Arrow, 2000). Many studies also indicate that social structures, including extended family, religious organizations and social clubs, provide both information and resources crucial to the venture's development (Jack \& Andersen, 2002; Davidsson \& Honig, 2003).

\section{NETWORKS AND RESOURCES}

As mentioned in the introduction, small innovative ventures are exposed to specific risks and opportunities. For example, where established firms can use their existing resource base or established contacts with suppliers to foster new innovative activity, independent ventures are generally more resource constrained, and have to establish new ties with potential suppliers and customers. This requires a certain measure of agility and flexibility on behalf of the small ventures. The literature often uses chess as a metaphor for the planning orientation of corporate strategy. In new venture development, poker is sometimes suggested as an alternative metaphor, because: "you play each hand as it is dealt and quickly vary tactics to suit the conditions" (Bhidé, 1986, p. 62). This short-term focus is often attributed to a lack of financial and other types of resources (Birley, 1985; Starr \& Macmillan, 1990). Many studies have noted that new independent ventures have trouble finding financial capital on the open market (Bhidé, 1992) forcing them to use different forms of financial bootstrapping. Winborg and Landström (2001) describe six broad categories of bootstrapping techniques: obtaining support including unsalaried work from owner/managers and relatives; management of accounts receivable such as speeding up invoicing; sharing and borrowing resources from external actors; delaying payments which includes leasing or renting instead of buying; minimization of investment in stocks, for instance through good relationships with suppliers; and obtaining subsidies from different public agencies.

Bootstrapping techniques allow entrepreneurs to develop their ventures at a minimum of financial risk. This relates to venture development strategies based on taking affordable risks rather than trying to maximize returns (Sarasvathy, 2001), seeking pre-commitments from stakeholders as a way to reduce uncertainty (Garud, Jain, \& Phelps, 1998) and more generally adapting the businesses in accordance with external demands (Bhidé, 1986). These techniques tend to rely on networking and establishing relationships 
that go beyond mere exchange of resources. To further probe this relationship, we present two case studies that illustrate how collaboration in social networks can be beneficial for new ventures with a limited resource base.

\section{Case Illustrations}

The following two cases illustrate the quite different roles social networks can play in venture development processes. Traditionally, the role of networks in innovation has been investigated from either a structural or an individual perspective. This study departs from these traditions by taking the developing venture as the focal unit of analysis. Individuals and networks are thus seen as ancillary, as focus is on how various individuals in different ways contribute to the venture development process. This is in line with Van de Ven's (1986, p. 591) description of the innovation process as "development and implementation of new ideas by people who over time engage in transactions with others within an institutional context."

The two cases are similar in many respects. They both developed in the same part of rural Sweden, are in their early stages and center around innovative product ideas based on patented inventions. At the same time, they differ radically in the way networks and relationships are used. We gained access to the two ventures from their connection to a professional network consisting primarily of innovators and entrepreneurs. We followed the ventures from spring 2004 until summer 2005 and the cases descriptions are based analyzed of seven face-to-face interviews lasting on average 2 hours, 12 telephone interviews of varying length, and over 20 e-mails with follow-up questions. We also downloaded annual statements and patenting information from publicly available sources. Furthermore, we were allowed to examine (but not take away) copies of board meetings, and to examine other written material such as business plans and market surveys.

The ventures were both initiated a few years before the first interviews. Information retrieved about these years may therefore suffer from a number of retrospective biases. To reduce these problems we employed a careful stepby-step approach when analyzing and writing up the case histories. The existence, timing, and nature of all past and current critical events have thus been verified by approaching at least two different individuals on different occasions (cf. Van de Ven, Polley, Garud, \& Venkataraman, 1999). When interpretations clearly conflicted, the two researchers listened, read, and compared interview material with archival data before arriving at a common interpretation. This procedure allowed us to check different sources against each other, thereby producing a more valid account of both the nature of 


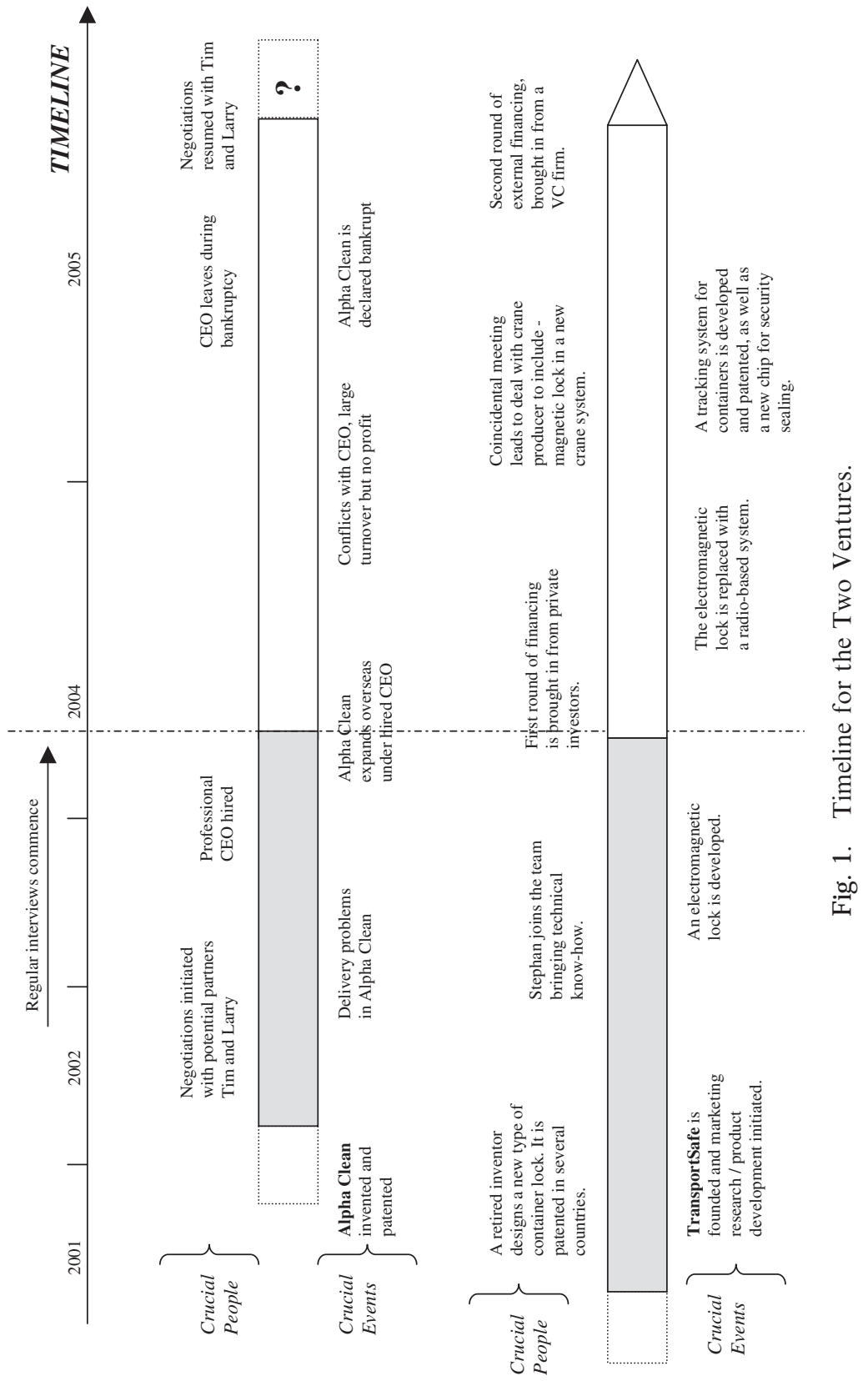


Table 1. Characterizations of the Two Ventures.

\begin{tabular}{|c|c|c|}
\hline & Alpha Clean & TransportSafe \\
\hline No of initial partners & 2 & 3 \\
\hline $\begin{array}{l}\text { No of partners added/ } \\
\text { dropped }\end{array}$ & $\begin{array}{l}\text { Prof. CEO added } \\
\text { CEO sacked }\end{array}$ & $\begin{array}{l}2 \text { founders retired } \\
1 \text { technician added } \\
1 \text { active investor added }\end{array}$ \\
\hline Invention & Internally generated & Acquired/Internally generated \\
\hline Initiation & 2002 & 2001 \\
\hline Product(s) & Hand-held cleaning machine & $\begin{array}{l}\text { Twistlock for containers ( } 3 \\
\text { versions developed) } \\
\text { Container tracking system } \\
\text { Container security seal }\end{array}$ \\
\hline Business model & $\begin{array}{l}\text { Changed ad-hoc due to } \\
\text { marketing difficulties }\end{array}$ & $\begin{array}{l}\text { Changed several times } \\
\text { New products developed } \\
\text { New market discovered } \\
\text { Partnering with big firm }\end{array}$ \\
\hline Capital structure & $\begin{array}{l}\text { Founders' capital } \\
\text { Local innovator grant }\end{array}$ & $\begin{array}{l}\text { Founders' capital } \\
\text { Public innovation grant } \\
\text { External capital (private) } \\
\text { External capital (VC) }\end{array}$ \\
\hline Gross sales 2004 & $\$ 1,200,000$ & $\$ 29,000$ \\
\hline Status spring 2004 & $\begin{array}{l}\text { Distribution problems } \\
\text { Beginning international sales }\end{array}$ & $\begin{array}{l}\text { Developed radio lock } \\
\text { First round of financing (private } \\
\text { capital) }\end{array}$ \\
\hline Status summer 2005 & $\begin{array}{l}\text { Pending bankruptcy } \\
\text { Trying to re-start }\end{array}$ & $\begin{array}{l}\text { Deal signed with partner } \\
\text { Production tests started } \\
\text { Completed second round of } \\
\quad \text { financing (VC) }\end{array}$ \\
\hline $\begin{array}{l}\text { Team's previous } \\
\text { experience }\end{array}$ & $\begin{array}{l}\text { Technical experience } \\
\text { No entrepreneurial experience } \\
\text { Contracting necessary skills }\end{array}$ & $\begin{array}{l}2 \text { members earlier } \\
\text { entrepreneurial experience in } \\
\text { same industry } \\
\text { Complementary skills }\end{array}$ \\
\hline
\end{tabular}

social relations and the venture development process in general. The overall development of the ventures and critical events are indicated on the timeline in Fig. 1, which follows after the case histories. In Table 1 below we also list some general characteristics concerning the two ventures. The table indicates the difference between the two ventures in terms of team structure, product and business model development, and in particular, the status and financial 
success of the ventures. While the first venture, Alpha Clean, clearly had a much higher market impact during the year of study, the case studies indicate the second venture, TransportSafe, as the more successful one.

\section{ALPHA CLEAN}

Before starting Alpha Clean, the founder-manager Steve considered his active career to be behind him, and with extensive experience from machine tool repair shops and development projects for the military and large private firms, he had no problems getting by on part-time work and temporary contracts. The idea for Alpha Clean originated when Steve's son took a job cleaning machine rooms and other risky facilities. The work environment was quite demanding with winding stairs, narrow passages and hard to reach areas around very sensitive equipment. Since the available cleaning machines were bulky and unsuitable for usage on uneven floors, work was very hard and labor intensive. Steve, therefore, tried to rebuild a few of the smaller cleaning machines available on the market, but without much success. After several attempts, he eventually constructed a completely new type of portable scrubbing machine, based on the technology used in automatic toothbrushes. Steve's son tested the machine in various setting such as staircases, high walls, crowded industrial kitchens and other awkward places. The machine performed much better than anything he had seen on the market and together father and son were convinced that this could become a commercially successful product. Steve quickly applied for a patent and soon thereafter approached the cleaning division of a large home appliances firm. The manager responsible for the 'wet cleaning' product division was positive and signaled an interest in developing the product. However, one month after talks had been initiated, the firm unexpectedly pulled back, citing a review of their overall product portfolio.

Steve and his son eventually decided to pursue the project themselves. Being new to the region, they lacked business contacts and therefore approached the local chamber of commerce. They found that their firm was eligible for 'innovator grants' from the local economic development authority. With these limited funds, Steve hired an industrial designer to finish the product. They then negotiated with a number of assembly plants with excess capacity, and after three months, contracted a firm to produce the cleaner. The only drawback was that the firm was located quite far away from Alpha Clean's location in a regional distribution hub. According to Steve this was discussed as a potential problem and therefore he was 
careful to specify explicit delivery details in the final contract. From his long experience in the military sector, Steve felt quite comfortable with minding his part of the bargain and not to develop any deeper contacts with his distributors:

\footnotetext{
"We needed a decently priced subcontractor and finding [this subcontractor], I was careful to outline everything I needed in the contract, that's the way I'm used to [handle] things. All nearby plants were either too expensive or lacked capacity to help us. I really didn't know anyone [nearby] that could do this, so it had to be this firm."
}

The final product was light and easy to use, with replaceable scrubber heads at the end of an adjustable 'broomstick.' Attached to the stick was a small water tank with an electric pump connected to the scrubber heads. They applied for European, Japanese and American patents, and Steve's son also tested the final product at home and at various industrial facilities.

A few machines had been sold for testing and development purposes at an early stage, but now it was time to start selling on a larger scale. The large cleaning firms had centralized purchasing departments and Steve found it difficult to bypass their established relationships with existing producers of cleaning machines. Instead, he approached local cleaning machines retailers directly who supplied equipment to the large, but highly fragmented, segment of small- and medium-sized cleaning firms. This segment includes countless small-scale cleaning firms, companies with their own in-house cleaning division, and private users. At this point, Steve's son was handling most of the sales and since the first batch ordered from the assembly plant was quite large, he decided to introduce a discount system that would get distributors to buy more products. After a slow start the first few months, sales suddenly took off sharply. Since the first batch was not yet produced, the company had to introduce a formal waiting list for new customers. Given the high demand for the product, Steve decided to hire a professional CEO to build up a small sales force and begin to market the product overseas.

At this point, we begin to follow Alpha Clean through regular interviews. Via the local Chamber of Commerce, Steve came in contact with a local innovator's network. The other people in the network liked Steve and appreciated him as a knowledgeable "old-fashioned inventor." As such, he differed from many of the young and typically IT-oriented entrepreneurs of the time. Steve himself did not think much of the people at the Network:

\footnotetext{
"I never really liked it at those [Network meetings], you know. Sure, I met some nice people there and many where really interested in us. But that bothered me, the whole I'll scratch your back you'll scratch mine attitude. And then it was that collaboration that never came through, and those people really irritated me."
} 
This collaboration refers to contacts taken by Larry and Tim who had been involved in initiating the local innovator's network and were also responsible for organizing the monthly meetings. Tim first met with Steve at the Chamber of Commerce, where he had recommended a production consultant who could pre-test and improve their product. Larry and Tim convinced Steve to present Alpha Clean at one of the Network meetings. After the presentation, Steve told Larry and Tim that the venture was having problems and that he could use some advice. Despite huge demand for the product and fairly low production costs, Steve had significant outstanding debts and the cash flow was very low. The problems could be attributed to production delays combined with low profitability on the products sold so far. Despite their assurances, the manufacturer had incurred repeated delays. Steve's contract with the plant clearly stipulated regular delivery of products. Despite this, the first batch had been delayed several months. Shifting to another production plant was too costly and the lack of funds meant Steve could not afford to enforce his contract. All he could do was to keep scolding the assembly firm for not shipping in time.

On hearing about the problems, Larry and Tim agreed to discuss how to resolve the predicament. They were both interested in the project and tried to get Steve to take them in as partners. Tim explained his view of the problem:

\footnotetext{
"I was astounded by his choice of production facility. Sure, it was cheap enough, but why the heck did he choose that far-away location instead of something nearby? It must have contributed to him losing track [of the production progress]."
}

Regarding the production situation, Larry and Tim could not help Steve beyond saying that a more accessible plant would have been better. When it came to discussing sales, Larry soon realized that this was big problem for the venture. He tried to convince Steve that a long-term sales strategy was important, and that such a strategy had to consider Alpha Clean, the end customer, as well as the middle man. Until now, Steve's son had been in charge of sales and marketing. He soon realized that the cleaning equipment retailers only bought one or two products at a time in order to maintain a small stock. To boost sales, he had introduced a discount system that offered 20 percent discounts if customers bought more than 5 machines, and 50 percent discount for more than 10 machines. At the meeting with Steve and his son, Larry scolded the strategy and explained his reason to do so:

\footnotetext{
"He had listed all distributors on his web-site, to gain credibility or something, I dunno. Apparently, the distributors had simply got together to buy in bulk and get the large discounts offered. So he sold the products beforehand at a 50 percent discount, and when the first few batches took several months to deliver, he had to offer some of them even higher discounts for them not to cancel their orders."
} 
In the end, despite low production costs and good sales, Alpha Clean made almost no profits. At this point in time, production had also begun to pick up and the firm had employed two secretaries and the production consultant that Tim had recommended. Money started to come in to the company, but flowed out just as fast. After two weeks of meetings and informal advice, Larry and Tim offered Steve a deal. They wanted to enter the venture as equal partners, but in order to get rid of the poor agreements with the manufacturer and current customers, they suggested that the patent, which was Steve's and not the firms, should be transferred to a new company that would be jointly owned by the three of them. Steve wanted none of this:

\footnotetext{
"They just acted like they knew what was best for me all the time. Do this! Do that! It was my invention. I didn't need anyone in the driving seat telling me what to do. All I needed was advice on how to manage this sales network, which obviously didn't work."
}

The negotiations with Larry and Tim ended in disagreement and bad spirits. Instead Steve promoted the production consultant that Tim had recommended to CEO and put him in charge of the firms' international expansion. The consultant had impressed Steve by speaking six languages and boasting lots of overseas business experience. Steve was confident that a professional CEO would be able to handle "much of the management details." Soon after having been promoted, the CEO went on to set up a Paris office from which to manage the European expansion. Steve designed an elaborate contract that included incentives to boost sales and establish new contracts with local dealers in different countries. The contract also included a very generous severance package. This proved to be a big mistake:

[Steve]: "In the first half year of international expansion, everything went well. We finally had production on line, and the international deals made up for the bad first deals in Sweden. And we were selling a lot! Actually, we where selling so much I was surprised that not more money was flowing in.

As Steve and his son looked into the accounting of Alpha Clean, they began to suspect that the CEO had embezzled money from the overseas sales. However, they had no clear evidence and the CEO vigorously rejected the accusations. Still, it was apparent that the CEO had signed a number of highly questionable long-term contracts with overseas partners. The worsening relationship between Steve and the CEO did not help business, and since the international contacts were handled by the CEO personally, not much could be done about the situation. Steve realized he had to get rid of the CEO to turn the venture around. Unfortunately, the severance deal meant that this was quite an expensive alternative. This was a very difficult 
period for Steve and during the spring of 2005 he left the day-to-day operations to his son. At this time Steve only gave interviews over the phone:

"Last year we sold over one million dollars but at the end of the day there was nothing left. After all our hard work! I felt like crying."

Steve and his son thought of alternatives that would secure the future of the firm. In May 2005, they declared Alpha Clean bankrupt. Apparently this was the only way to get rid of the CEO and get out of the poor contracts he had signed. Steve and his son lost their invested equity, but the patent was still theirs. As of summer 2005, Steve wanted to discontinue the interviews, clearly feeling bad about the way things had turned out. He was back negotiating with his old contacts Tim and Larry, about possible financial restructuring and re-start of the firm.

\section{TRANSPORTSAFE}

TransportSafe started with a famous Swedish inventor who, during his retirement, had produced and patented a new type of mechanic twistlock for loading and unloading shipping containers. After his retirement, the inventor moved to a small city in rural Sweden where he became neighbors with Bill. At the time Bill was involved in a partnership trying to market a new type of absorption material for container use. As Bill's current venture was reaching a dead-end, he suggested to his partner John that they abandon the current idea and approach the inventor. The inventor agreed to sell the invention in exchange for cash and a partial ownership in the new firm that the three of them set up. John, who knew a lot of wealthy people from his earlier job as a tennis instructor, approached one of his friends and convinced him to invest in the firm. This provided the capital injection necessary to start developing the invention. With the experience from the shipping industry from their former venture, John spent a couple of months traveling the world doing market research, talking to industry specialists, dock and shipping managers, and the like.

He realized that there was a huge market that has not been modernized in many years. All available twistlocks were either manual locks that were locked and unlocked by hand, or semi-automatic locks that closed automatically but had to be manually unlocked before containers could be unloaded. This meant huge labor expenses for the shipping business, which had to employ large numbers of stevedores to climb the containers on ship decks to lock and/or unlock containers, often stacked up to eight containers 
high. Calculating that a large ship carries over 6,000 twistlocks, John saw a hefty profit to be made for anyone who managed to produce a lock that could reduce the problem of manual locking and unlocking.

The suggested twistlocks relied on guiding wires that allowed ship operators to open them by pulling a trigger connected to the crane, lifting the containers. John had a factory produce a dummy of the lock, an impressive one-foot 45-pound piece of solid iron. Bill, John, and the inventor approached a big crane company in the shipping business. The company showed interest and organized a presentation of the product during a pan-European sales conference. The idea was met with skepticism by the gathering of international salesmen, especially regarding the robustness of the guiding wires supposed to connect to the container locks. The inventor then asked:

"But we have also been talking about doing an electromagnetic version of this lock, where the guiding wire goes down with a small magnet, and an electronic engine pulls down a small lever to connect the magnet."

This was clearly more interesting for the people at the conference. But how would they produce this? John and Bill were not technicians, the old inventor had no experience in electromagnetic applications and also his health condition was getting worse. John, who had participated at a few meetings with the local innovation network, remembered a retired technical manager who was working part-time as a consultant in various product development projects. John went to meet with the consultant, Stephan, and explained the idea with the big iron lock in front of them on Stephan's porch table. Was Stephan interested and able to design some sort of electromagnetic tool to operate the lock?

Stephan joined the venture, putting up a trickle of money and buying into the venture. For a small consulting fee, he together with a few former colleagues managed to produce the suggested electromagnetic tool in three months. John's friend, who had invested most of the money, provided a second small capital injection together with a group of wealthy businessmen. This is the point where we came in and began to follow the venture. It was yet unclear who would be the customer of the product. Bill had now stepped back as a passive owner as he felt he had little to contribute to the current state of the venture. The original inventor had also withdrawn. John and Stephan approached the main European shipping firms to investigate their interest. The reaction of the biggest shipping firm was negative:

\footnotetext{
"Why are you still doing that thing with the guiding wires? On our new boats we are trying to replace the 40 -feet containers with 45 -feet [containers], there's no chance you could fit those guiding wires down on the sides. What we want is a purely automatic lock! Come back if you have something [like an automatic lock]."
} 
Disappointed, John and Stephan discussed with their board what to do. According to Stephan, the highly magnetic environment of container docks would make it extremely difficult to get a reliable radio signal through. Their lawyer suggested they liquidate the firm and try to sell the existing patent since the business idea seemed unfeasible and keeping the patent internationally active was expensive. The current investors, however, wanted Stephan to investigate the possibility of a radio-based locking system. At least they knew that the shipping industry was interested and that nobody else seemed to have such a system.

Stephan searched his former colleagues and eventually found that one of them was managing a research group in microwave engineering at the local university, looking for new projects as the telecom industry was cutting back on R\&D. On behalf of TransportSafe, a research group was set up and in only six weeks they had managed to modify the lock so that a radio signal from a loading crane would be able to open and close the lock. The final lock, operated by remote control, seemed to be the first such solution in marine history. TransportSafe immediately applied for worldwide patents.

One of the new investors in TransportSafe had also joined the management team as a production specialist. He negotiated with a factory that could cast the non-electronic parts of the locks; however, they where hesitant toward the project as it would entail significant initial costs in producing molds and running trial batches. The newly patented radio system together with an official letter of interest from the director of the large shipping firm was used as support in discussion with the casting factory, and finally the manager of the casting factory was convinced:

\footnotetext{
"See, we didn't believe in the project to start with, [it] all sounded kind of hazardous and untested, producing a large batch of a completely new type of lock. This is a highly centralized market, you know. Though we liked them [the TransportSafe team], we couldn't bet on the project to succeed. We needed something, and I believe by that [recommendations from the shipping firm] they gave an argument that I could present for my boss."
}

During the renewed talks with the shipping firm, a new idea was initiated. Although safe transports was still of key interest for the firm, another issue had climbed to the top of their agenda: that of security. As John explained:

\footnotetext{
"They [the shipping firm] told us that the radio link was all great. But it will take time and come through with new cranes for the harbors. And it seemed the harbors were pressing the [shipping] industry to improve upon security. The heightened awareness of this since September 11 brought up the issue of the immense difficulties in keeping track of containers. A harbor manager even said that over ten percent of all containers are lost when they are unloaded and it usually takes several days to find them. Imagine, Ten percent! Of all the million containers out there, every day. I saw that this could be an important area."
} 
The reason it was impossible to keep track of containers was that the general GPS system could not be used to pinpoint containers due to radiation and magnetism generated by the metal containers in a dense harbor. The engineering group employed by TransportSafe therefore constructed a small transponder that could be activated when the ship unloads. Since all ships are controlled by GPS, it would thus be possible to link a particular ship to its containers. This seemed to be exactly what the shipping firm was interested in. In addition, an electronic seal was developed to record when and for how long a container had been opened. TransportSafe now had three patented products: First, the radon lock that facilitated loading and unloading of containers. Second, the tracking system that would help shipping firms keep track of their containers, ensuring delivery-on-time for the customer as well as improved security for harbors and authorities. And third, the security seal that made sure that no one unauthorized to do so could put something in a container during transportation.

Now the question was how to proceed with selling the products. The tracking system and security seal only existed as prototypes and the radio lock was not compatible with the current container and crane standard. The big shipping firms had expressed their interest, but discussions in the venture now centered around who should be the final customer, shipping firms or harbor management firms? As the question was pondered and tested on various possible customers, Stephan was contacted by a delegation from the Chinese Shandong province, currently on visit in Sweden. Since China is of key interest for anyone seeking business in the shipping industry, Stephan invited the delegation for dinner in his big summer house. The delegation was administered by a Chinese woman married to a Swedish executive at a big crane-producing firm. Stephan described the meeting as a coincidental stroke of luck:

"When he asked me what I was doing I replied 'Well, I'm working in a start-up developing automated containers locks', the executive replied 'Heck, automated shipping systems, that is what we are doing!"

It turned out the big crane firm was trying to automate their crane system to sell at harbors, and they needed a product just like TransportSafe's. Could they license the radio lock system? After lengthy negotiations, a deal was made where the crane firm would handle sales and marketing to harbors, buying the electronic locks from TransportSafe for inclusion in their crane systems. TransportSafe would also sell the new locks directly to shipping firms, with the crane firm taking a small percentage for the lock 
to be sold jointly under the crane firms and TransportSafe's labels. A professional CEO with experience from the shipping industry was recruited and TransportSafe began to look for an investor to bring in a round of capital until the firm could achieve profitability. They negotiated with several venture capital (VC) firms as well as a public investment agency.

In spring 2005, a VC firm with strong regional ties bought a large minority post in TransportSafe. This guaranteed funding for at least a couple of years, given the current level of operations. John and Stephan's active roles in the company's management now declined and instead the $\mathrm{CEO}$ and his newly recruited production consultants gradually took over most of the day-to-day management. An electronics supplier had been contracted so the priority now was to develop the production system with the firm that would produce, cast and assemble the lock. The first batch was scheduled for late 2005, with marketing activities to commence the following year. With the original venture team taking positions as board members or passive owners, the case study was concluded on a very positive note in the summer of 2005.

\section{DISCUSSION}

Both Alpha Clean and TransportSafe started with patented innovations that were exploited in independent ventures, targeting established industries. However, the ways the ventures developed was very different. In Alpha clean, the inventor Steve was also the entrepreneur and even though he interacted with external stakeholders he was reluctant to let others influence the venture development process. In TransportSafe, the original inventor let go of his idea, and as the venture developed the leading individuals were often replaced by others, which led to a continuous infusion of alternative perspectives and ideas.

Both cases highlight the important role of social networks in the venture development process. The story of TransportSafe particularly illustrates how social networks and the opportunities they reveal can have a major effect on the direction and structure of ventures. In what follows we take the two cases as point of departure to glean three more general lessons relating to ownership of the innovation process, focus on risk or uncertain opportunities, and the relationship between network embeddedness and bootstrapping. 


\section{INDIVIDUAL OR SOCIAL OWNERSHIP OF THE INNOVATION PROCESS}

A key difference between the two ventures' network structure was that TransportSafe through their different stakeholders had a larger number of embedded ties, and more variation in type of embeddedness. Alpha Clean primarily relied on formal contracts and the embedded network ties of the father-and-son founders seem to primarily have grown out of their prior economic interaction with various individuals. TransportSafe on the other hand used both formal and informal contracts in interaction with others, and the embedded network ties of the founders seem to have grown out of a combination of personal relationships, social capital, and economic interaction.

Arrow (2000) argues that all agreements to cooperate involve non-economic understandings in addition to those that are specified in a formal contract. Such non-economic understandings would be relatively more important for new independent ventures that are in weak positions to enforce contract compliancy due to their limited resource base (Bird, 1995). This framework would explain the outcome of Alfa Clean as being negatively affected by a lack of supportive non-economic relationships. This concerns Alfa Clean's insufficient governance mechanisms, namely the assembly plant, sales agents, and the hired CEO. Choosing an effective governance mode requires consideration not only of the transaction, but also of the type of relationship (Hite, 2003).

\section{FOCUS ON RISK OR OPPORTUNITIES}

A related issue concerns whether focus in a new independent venture is on managing perceived risks or exploring uncertain opportunities. Many of the differences between the two ventures seem to hark back to a focus on handling the existing risks or exploring uncertain opportunities. Alpha Clean and its owner-manager Steve sought to avoid uncertainties. The main priority was to keep existing risks under complete control. This was evident in relationships with other organizations as well as with individuals. In either case Steve's goal was to maintain control and only enter into relationships that could be clearly specified from the outset. Alpha Clean thus tried to draw up explicit contracts to handle the visible risks, but paid little attention to uncertain issues that were not directly obvious. This indicates a view of 
the future as predictable. If, on the other hand, the future is seen as highly uncertain and unpredictable, actions need to be based on vague perceptions of benefits that are not always conceivable at the present time (cf. Lane, Malerba, Maxfield, \& Orsenigo, 1996). Allowing new people to influence a venture, means that new skills and also a wider network is brought to bear on the venture. This increases the likelihood that it will develop in novel ways that could not be perceived from the outset.

The openness to uncertainty seemed to pervade TransportSafe. For instance, the originally negative response from the large shipping firms triggered a broad search for potential solutions. Without knowing what he might find, Stephen contacted some old colleagues and happened to come across a potential solution that would lead the venture in a radically new direction. The TransportSafe story also indicates that network contacts can be providers of tangible resources, but also have reputational or signaling content. This is exemplified with how TransportSafe used their biggest potential customer, with whom they had close ties, as a reference to the casting factory that were hesitant to accept the initial order for casting the new container locks. In the uncertain and dynamic environment of new independent ventures, resource holders such as the TransportSafe's casting factory are likely to seek information that helps to gauge the underlying potential of a venture (Hoang \& Antoncic, 2003).

To summarize, a focus on clearly perceived risks may lead to an overly defensive attitude where uncertain alternatives with great potential may be neglected. It would seem that entrepreneurs should be careful to not only manage risk, but also to consider the opportunities available in the uncertain future, even if potential gains are often hidden. Taking a cue from the discussion of social ownership, a focus on exploring uncertain opportunities rather than managing risk suggests a more creative role of financial bootstrapping than is typically described in the literature.

\section{NETWORK EMBEDDEDNESS AND BOOTSTRAPPING}

Hite's $(2003,2005)$ classified entrepreneurs' social network according to three types of relationships: personal relationships, social capital or economic interaction. The two cases exemplify how network relationships relate to the types of bootstrapping techniques available for entrepreneurs (Winborg \& Landström, 2001). TransportSafe frequently used unsalaried work from friends and colleagues of the venture team. The strategy was taken one step further as lawyers, technical designers and others with important skills were 
actively invited to join the venture team as either employees or board members. The venture also managed to access cheap external resources as in the case of the local research team, or when the casting factory was persuaded to share the risk of producing the first trial batch (Garud et al., 1998). By using bootstrapping techniques like these, TransportSafe was able to identify a broader range of ideas and options, besides lowering direct costs of development. Alpha Clean initially used some typical bootstrapping techniques, such as seeking subsidies from public agencies and obtaining support in the form of unsalaried work from owners and relatives. Most of the resources, including design expertise and production, were however bought on the open market with involvement regulated in formal contracts.

A key assumption in the bootstrapping literature is that lack of resources forces entrepreneurs to experiment with alternative solutions, such as getting access to resources obtained from external stakeholders or the entrepreneurs' friends and relatives. However, two cases suggest that individuals with more management experience and richer personal networks, tended to use more external contacts regardless of the resource needs of the venture. This indicates that the network relationships available to a new venture, affect what types of bootstrapping techniques are employed. It also seems that entrepreneurs with extensive and well developed social and professional networks have a large collection of contacts that can introduce them to new stakeholders. Conversely, entrepreneurs with more limited social networks find more of their bootstrapping opportunities in personal relationships with friends and family. This resonates with Cooper, Folta, and Woo (1995) who found that inexperienced entrepreneurs tend to rely on personal ties such as family, friends, and other business owners, whereas experienced entrepreneurs rely more on professional contacts such as lawyers and accountants during their start-up phase. Examples of how network embeddedness is related to the type of relation embeddedness are described in Table 2.

It is interesting to note that TransportSafe, which received two rounds of external funding, still relied heavily on bootstrap techniques. Judging from the constructive effects these relations had on the development of the venture, it seems reasonable to suggest that the rationale for using bootstrap techniques should be extended beyond economic necessity to also include its role as a creative venture development strategy. To the extent that bootstrapping techniques rest on embedded network ties, they serve to generate and validate ideas regarding the venture's focus and business model. A creative function for bootstrapping techniques seems to fit with the idea of social ownership of the venture development process and the focus on exploring new opportunities rather than managing perceived risks. 
Table 2. How Bootstrapping Activities Differ Depending on Relational Embeddedness.

\begin{tabular}{|c|c|c|}
\hline $\begin{array}{l}\text { Type of Network } \\
\text { Embeddedness }\end{array}$ & Bootstrapping Activity & Example from Cases \\
\hline $\begin{array}{l}\text { Personal } \\
\quad \text { relationship }\end{array}$ & Get friends involved & $\begin{array}{l}\text { John of TransportSafe } \\
\text { convinced an old tennis } \\
\text { friend to invest the first } \\
\text { money in the firm }\end{array}$ \\
\hline Social capital & $\begin{array}{l}\text { Use network to establish contacts } \\
\text { with potential suppliers, } \\
\text { investors, etc }\end{array}$ & $\begin{array}{l}\text { Steve of Alpha Clean } \\
\text { approached the } \\
\text { professional network and } \\
\text { received help from Tim to } \\
\text { hire a production } \\
\text { consultant, whom later } \\
\text { became the firm's CEO }\end{array}$ \\
\hline $\begin{array}{l}\text { Economic } \\
\text { interaction }\end{array}$ & $\begin{array}{l}\text { Convince potential suppliers, } \\
\text { auditors etc. To provide } \\
\text { resources and services without } \\
\text { monetary remuneration, instead } \\
\text { taking up residual claim in the } \\
\text { firm (e.g. stocks, licensing deals) }\end{array}$ & $\begin{array}{l}\text { Stephan of TransportSafe } \\
\text { crane negotiated a deal } \\
\text { with a large crane firm that } \\
\text { would take care of } \\
\text { marketing and sales of } \\
\text { TransportSafe's main } \\
\text { product under a joint label }\end{array}$ \\
\hline
\end{tabular}

This extends suggestions Johannisson (2000), Sarasvathy (2001) and others by showing how informal tactics for attaining financial resources are part of the creative strategies by which ventures enact the future through the formation of an expanded network of stakeholders.

\section{CONCLUSIONS}

Social networks are essential for understanding the innovative processes in new independent ventures. This study presented two cases and extracted some tentative insights about how social networks can influence the innovative processes in new independent ventures. However, one should be careful when judging the present findings in the light of the venture outcomes. Both ventures had their ups and downs and if the study had ended half a year earlier, Alpha Clean would have come across as the great success with tremendous potential for international expansion. The results should therefore be seen as elaborations of the role played by social networks in the innovation process. 
A key lesson from this study is that venture development can be facilitated by a gradually evolving coalition of stakeholders whose contributions make it possible to explore the uncertain opportunities that new ventures face. If venture ownership resides with a single individual or a homogeneous group, the venture may miss important avenues for action. By bringing more people in, more potential opportunities may be identified. However, individuals' interests and knowledge might also constrain perspectives and possibilities for development. As a venture grows and changes it may therefore be important not only to manage the expansion of the network of stakeholders, but also to make sure that some people leave or at least stop influencing the venture. A related lesson concerns the distinction between risk and uncertainty. If a new independent venture focus on managing clearly perceived risks, it is likely to ignore vague but important opportunities. Leaders of innovative processes in new ventures would benefit from trying to promote and invest in new ideas, despite their inherent uncertainty (Matthew \& Sternberg, this volume).

The importance of social ownership and openness to uncertainty also help us understand the affects of bootstrapping. Obtaining support from external sources can be facilitated by socially embedded network ties, regardless of the resource needs of the venture. This means that bootstrapping is not only a reaction to economic necessities but also a creative strategy of venture development. This understanding of bootstrapping techniques provides a practical illustration of ventures as an expanding network of stakeholders (Larson \& Starr, 1993; Johannisson, 2000). The cases also indicate that entrepreneurs with strongly embedded ties can leverage their venture development process by using relationship-based bootstrap techniques. This should be an important consideration for practicing entrepreneurs with a limited resource base.

The role of social networks for new independent ventures can also be of interest for policy makers: Currently, much effort and resources are spent by policymakers trying to increase entrepreneurship either from society's supply side or demand side, for example by increasing the attractiveness of entrepreneurship as a career choice or lowering the tax rate for new firms (Stevenson \& Lundström, 2002). By supporting the establishment and development of professional networks, such as the one mentioned in this article, policy makers can help to facilitate contacts and exchange of ideas between innovators, entrepreneurs, financers, and other key actors in the innovation process. Specifically, policy makers who seek ways to enhance the resource base of new ventures, for instance by public innovation grants or other types of public support, need to understand that resources acquired 
through networking activities have important additional benefits. By encouraging networking, perhaps by supporting local inventor's associations, policy makers may indirectly help the development of more sustainable ventures than does the handing out of direct support.

\section{ACKNOWLEDGMENTS}

Both authors contributed equally in writing this chapter and are listed reverse alphabetically. We are grateful to Johanna Levallius and Ingela Sölvell for helpful advice. Remaining errors are entirely our own.

\section{REFERENCES}

Arrow, K. (2000). Observations on social capital. In: P. Dasgupta \& I. Serageldin (Eds), Social capital: A multifaceted perspective (pp. 3-5). Washington, DC: World Bank.

Bhidé, A. (1992). Bootstrapfinance: The art of start-ups. H arvard B usiness R eview, 70, 109-117.

Bhidé, A. V. (1986). Hustle as strategy. H arvard Business R eview, 64, 59-65.

Bird, B. (1995). Toward a theory of entrepreneurial competency. In: J. A. Katz \& R. H. Brockhaus (Eds). Advances in entrepreneurship, firm emergence, and growth (Vol. 2, pp. 51-72). Greenwich, CT: JAI Press.

Birley, S. (1985). The role of networks in the entrepreneurial process. J ournal of Business Venturing, 1(1), 107-117.

Chesbrough, H., \& Rosenbloom, R. S. (2002). Role of the business model in capturing value from innovation: Evidence from Xerox corporation's technology spin-off companies. Industrial and Corporate Change, 11(3), 529-555.

Cooper, A. C., Folta, T. B., \& Woo, C. (1995). Entrepreneurial information search. J ournal of Business V enturing, 10, 107-120.

Davidsson, P., \& Honig, B. (2003). The role of social and human capital among nascent entrepreneurs. J ournal of Business V enturing, 18(3), 301-331.

Garud, R., Jain, S., \& Phelps, C. (1998). Organization linkages and product transience: New strategic imperatives in network fields. In: J. Baum (Ed.), Advances in strategic management (Vol. 15, pp. 205-237). Greenwich, CT: JAI Press.

Greene, B., \& Brown, T. (1997). Resource needs and the dynamic capitalism typology. J ournal of Business $V$ enturing, 12(3), 161-173.

Greve, A., \& Salaff, J. (2003). Social networks and entrepreneurship. Entrepreneurship Theory and Practice, 28(1), 1-22.

Hite, J. M. (2003). Patterns of multidimensionality among embedded network ties: A typology of relational embeddedness in emerging entrepreneurial firms. Strategic Organization, $1(1), 9-49$.

Hite, J. M. (2005). Evolutionary processes and paths of relationally embedded network ties in emerging entrepreneurial firms. Entrepreneurship Theory \& Practice, 29(1), $113-144$. 
Hoang, H., \& Antoncic, B. (2003). Network-based research in entrepreneurship: A critical review. J ournal of Business V enturing, 18(2), 165-187.

Jack, S. L., \& Andersen, A. R. (2002). Effects of embeddedness upon the entrepreneurial process. J ournal of Business V enturing, 17(5), 467-487.

Johannisson, B. (2000). Networking and entrepreneurial growth. In: D. Sexton \& H. Landström (Eds), $\mathrm{H}$ andbook of entrepreneurship (pp. 368-386). London: Blackwell.

Lane, D., Malerba, F., Maxfield, R., \& Orsenigo, L. (1996). Choice and action. J ournal of Evolutionary E conomics, 6, 43-76.

Larson, A., \& Starr, J. A. (1993). A network model of organization formation. Entrepreneurship Theory \& P ractice, 17(2), 5-15.

Matthew, C., \& Sternberg, R. (this volume). L eading innovation through collaboration.

Sarasvathy, S. D. (2001). Causation and effectuation: Toward a theoretical shift from economic inevitability to entrepreneurial contingency. A cademy of M anagement Review, 26(2), 243-263.

Staber, U., \& Aldrich, H. E. (1995). Cross-national similarities in the personal networks of small business owners: A comparison between two regions in North America. Canadian J ournal of Sociology, 20(4), 441-467.

Starr, A. S., \& MacMillan, I. C. (1990). Resource cooptation via social contracting: Resource acquisition strategies for new resources. Strategic $M$ anagement J ournal(11), 79-92.

Stevenson, L., \& Lundström, A. (2002). Beyond the rhetoric: Defining entrepreneurship policy and its best practice components. Stockholm: Swedish Foundation for Small Business Research.

Van de Ven, A. (1986). Central problems in the management of innovation. M anagement Science, 32(5), 590-607.

Van de Ven, A., \& Engleman, R. (2004). Event- and outcome-driven explanations of entrepreneurship. J ournal of Business V enturing, 19(3), 343-358.

Van de Ven, A., Polley, D., Garud, R., \& Venkataraman, S. (1999). The innovation journey. New York: Oxford University Press.

Winborg, J., \& Landström, H. (2001). Financial bootstrapping in small businesses: Examining small business managers' resource acquisition behaviors. J ournal of Business V enturing, 16, 235-254. 